\title{
Physical and Chemical Characterization of Dust Deposited in the Turan Lowland (Central Asia)
}

\author{
Michael Groll ${ }^{1,}$, Christian Opp ${ }^{1}$, Gulnura Issanova ${ }^{2}$, Natalya Vereshagina $^{3}$, and Oleg Semenov ${ }^{4}$ \\ ${ }^{1}$ University of Marburg, Department of Geography, 35037 Marburg, Germany \\ ${ }^{2}$ Research Centre of Ecology and Environment of Central Asia, 050060 Almaty, Kazakhstan \\ ${ }^{3}$ UZHYDROMET, Hydrometeorological Research Institute (NIGMI), 100052 Tashkent, Uzbekistan \\ ${ }^{4}$ Kazakh Research Institute for Ecology and Climate, 480072 Almaty, Kazakhstan
}

\begin{abstract}
The desiccation of the Aral Sea ranks among the largest man-made ecological catastrophes and has become a global symbol for the overexploitation of limited resources and the environmental and socioeconomic consequences caused thereby. Formerly the fourth largest inland lake, large parts of the Aral Sea have been transformed into a salty desert - the Aralkum. The exposed lake bed sediments are subject to wind erosion, resulting in white sand and dust storms which have been tracked over several hundred kilometres using remote sensing images. Dust deposition data, on the other hand, requires excessive field work over prolonged periods of time and thus is scarce. But this kind of ground-based monitoring provides valuable insights into the physical and chemical composition of the transported material. The dust transported from the Aralkum contains, among other things, salts, heavy metals and agrochemicals deposited in the Aral Sea over decades. It can contribute to soil salinization, damage crops and technical infrastructure and impair the human health in the region surrounding the Aralkum, making the analysis of the aeolian dust deposition highly relevant. In the study presented here passive dust deposition data from 23 meteorological stations in the Turan lowland have been collected between 2003 and 2012 and analyzed for their grain size, mineralogical, and chemical characterization in order to identify the influence the newly formed Aralkum has on the Central Asian dust dynamic.
\end{abstract}

\section{Introduction and Study Design}

Water is a valuable resource and has to be managed efficiently, especially in Central Asia, a land-locked arid region with a population of 65.3 million. The water required for sustaining this fragile system comes from the Central Asian "water towers" [1] - the highly glaciated mountain areas of the Pamir and Tien Shan mountains. From there it feeds the two large Central Asian streams, the Amu-Darya and Syr-Darya. Together with the Aral Sea as their terminal lake they form the largest inland watershed worldwide [2, 3]. Steep mountain slopes, thin soils and low evaporation rates in the upper catchments lead to a rapid surface runoff, especially during the snow and glacier melt period in spring and summer, creating a good water supply in a region with overall little precipitation [4]. This combination of abundant water supply during the vegetative period and a hot and dry climate in the lowlands is well suited for agriculture. This was the basis for the elaboration of traditional irrigation schemes and the development of rich oasis cities in the land between those two streams (Transoxania $=$ "Beyond the Oxus River", the Oxus being an old name for the Amu-Darya) dating back for more than two millennia [5]. During the 20th century the land and water use intensified beyond sustainable measures and grand irrigation farming and hydropower plans were implemented. This overexploitation of the water resources led to a sizeable annual water deficit and to the largest man-made ecological disaster, known as the Aral Sea syndrome [69]. As less and less water reached the Aral Sea and the evaporation surpassed the freshwater inflow, the water volume and lake surface decreased, increasing the salinity of the lake's water to toxic levels (from $10.2 \mathrm{~g} / \mathrm{l}$ in 1947 to $80.0 \mathrm{~g} / \mathrm{l}$ in 2005 [10]). The extensive use of agrochemicals (fertilizers based on Ammonium, Nitrogen, Phosphor and Potassium, pesticides like DDT, Phosalone, Lindane or Toxaphene [11]) and salts leached from salinized fields in the Aral Sea basin further contributed to the accumulation of hazardous substances in the lake for many decades [6, 12-18]. The desiccation of the Aral Sea exposed the polluted lake bed sediments to the forces of the wind. The lake turned into a desert the Aralkum, covering more than $60,000 \mathrm{~km}^{2}$ (Fig. 1) [6, $7,19]$ - and wind erosion now remobilizes the salts and agrochemicals deposited in the lake over decades. These airborne pollutants are a potential health risk for the region surrounding this man-made desert $[6,7,15,20]$ and require a thorough monitoring. Due to the remoteness and size of the affected area of more than 1.5 million $\mathrm{km}^{2}$ spread out predominately over three

Corresponding author: mgroll@gmx.net 
countries (Kazakhstan, Turkmenistan, Uzbekistan) most studies focus on remote sensing as their primary data for the monitoring of the aeolian sediment transport [21-24]. But while satellite data can provide an area-wide quantification of the transported material and can also provide insights into the qualitative nature of the airborne dust due to its spectral characteristics, on-site measurements of the dust deposition and laboratory analyses of its mineralogical and chemical properties are needed to complement such a monitoring.

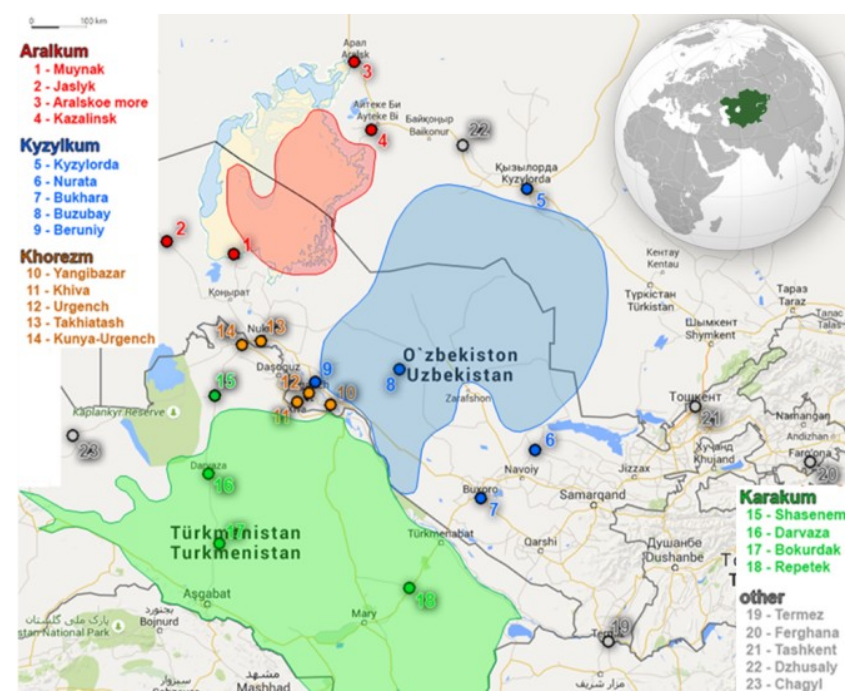

Fig. 1. Dust sampling sites and the three major dust sources Karakum, Kyzylkum and Aralkum

The study presented here collected monthly dust deposition samples from 23 meteorological stations in four regions (Aralkum, Khorezm, Karakum and Kyzylkum; Fig. 1) between 2006 and 2012. All collected dust samples (inverted Frisbee design passive deposition samplers in $3 \mathrm{~m}$ height; [6]) were weighted and selected samples (based on the available sample material) were used for the analyses of the grain size composition the mineral composition (using wavelength dispersive X-ray diffraction), and the chemical composition (using atomic absorption spectroscopy and X-ray fluorescence).

\section{Results}

The grain size analysis showed that the majority of the material deposited in $3 \mathrm{~m}$ height $(85.8 \%-97.6 \%$ in the four regions of the study area) was part of the $\mathrm{PM}_{5}$ group (fine silt and clay particles; $<0.0063 \mathrm{~mm}$ ) and that the average grain diameter ranged between $0.0018 \mathrm{~mm}$ and $0.0129 \mathrm{~mm}$. The Karakum is characterized by a unique much finer - grain size composition while the other three regions are very similar to each other (Fig. 2). The grain size averages across all sampling sites also show a seasonal dynamic as the deposited material is coarser in spring and summer than in winter, but even in March the percentage of $\mathrm{PM}_{5}$ material remains above $80 \%$. Throughout the study period the average grain diameter increased from $0.0019 \mathrm{~mm}$ in 2006 to $0.0141 \mathrm{~mm}$ in 2012 (with a maximum of $0.0214 \mathrm{~mm}$ in 2011). This indicates an increase in the wind energy (from $1.3 \mathrm{~m} / \mathrm{s}$ average wind speed during the first three years of the study period to $3.6 \mathrm{~m} / \mathrm{s}$ during the last three years based on monthly averages measured across all 23 meteorological stations) which also results in an intensification of the aeolian transport and the deposition rates (from $108.4 \mathrm{~kg} /$ ha average monthly dust deposition in 2006 to $195.6 \mathrm{~kg} / \mathrm{ha} *$ month in 2012).

The mineral composition of the dust samples allows a more differentiated view at the individual regions. Dust from the Aralkum and the Karakum is characterized by very similar minerals. Quartz, calcite, and dolomite were detected in the samples from both regions in nearly identical percentages (for a total of $65.6 \%$ in the Aralkum and $65.2 \%$ in the Karakum). But there are differences as well. The Aralkum dust samples contain hardly any illite $(0.56 \%)$ and showed the highest microcline contents across all regions $(4.97 \%)$. The dust from the Karakum, on the other hand, contained only $1 \%$ of orthoclase, but the highest concentrations of albite $(24.67 \%)$ and illite $(3.84 \%)$. The Kyzylkum is characterized by a very different mineral composition with an even spread of quartz, calcite, albite, dolomite, and orthoclase. The two latter minerals were far more common (18.8\% each) in the Kyzylkum samples than in the other regions, while quartz and calcite showed in the Kyzylkum samples the lowest percentage across all regions. Khorezm, as the in-between region that is also not a dust source, but a densely populated agricultural center was characterized by the highest percentages of quartz (34.5\%) and calcite (29.3\%) and the lowest values for dolomite $(9.7 \%)$. These results not only work as a mineralogical finger print of the different regions, but also give insights into the health risk that this mineral composition poses in aeolian dust of mostly $\mathrm{PM}_{5}$ size. Especially quartz, albite, and illite have a high potential of causing respiratory diseases [25-27], which are one of the main health concerns in the Aral Sea region (especially in Karakalpakstan and Khorezm) [17, 20, 28].

Due to the mineral composition of the dust samples, $\mathrm{SiO}_{2}$ is the most common compound detected in the Central Asian dust (on average 56.3\%), followed by $\mathrm{CaO}$ $(8.86 \%)$ and $\mathrm{Al}_{2} \mathrm{O}_{3}(7.8 \%)$. The Aralkum and the Kyzylkum are characterized by above average concentrations of the former two compounds $\left(\mathrm{SiO}_{2}\right.$ : $60.1 \%$ and $61.4 \%$, respectively; $\mathrm{CaO}: 11.7 \%$ and $13.4 \%$, respectively) while the Karakum samples showed above average concentrations of $\mathrm{Al}_{2} \mathrm{O}_{3}(8.7 \%)$ and below average concentrations of $\mathrm{CaO}(6.4 \%)$, but these differences are, overall, minor. More pronounced differences were detected in the minor compounds and the trace elements. The Aralkum dust samples, for instance, were characterized by a much higher concentration of $\mathrm{SO}_{3}{ }^{2-}$ compared to the Karakum and Kyzylkum (2,365 ppm vs. $232 \mathrm{ppm}$ and $512 \mathrm{ppm})$. Khorezm also showed a high value for $\mathrm{SO}_{3}{ }^{2-}$ $(1,681 \mathrm{ppm})$ and had the highest concentration of $\mathrm{P}_{2} \mathrm{O}_{5}$ $(1,857 \mathrm{ppm}$ compared to $1,074 \mathrm{ppm}$ in the Aralkum, 
$866 \mathrm{ppm}$ in the Karakum and $465 \mathrm{ppm}$ in the Kyzylkum). The high concentrations of phosphor in Khorezm and the Aralkum samples reflect the strong anthropogenic impact of local, agricultural dust sources (Khorezm) and the accumulation of agrochemicals in the Aral Sea sediments.

In order to characterize the four study regions further, the following ratios were calculated and compared to data from other dust sources: $\mathrm{K}_{2} \mathrm{O} / \mathrm{SiO}_{2}$ (K/S-Ratio); $\mathrm{SiO}_{2} / \mathrm{Al}_{2} \mathrm{O}_{3} \quad$ (S/A-Ratio); $\mathrm{K}_{2} \mathrm{O} / \mathrm{Al}_{2} \mathrm{O}_{3} \quad$ (K/A-Ratio); $\left(\mathrm{Na}_{2} \mathrm{O}+\mathrm{K}_{2} \mathrm{O}\right) / \mathrm{SiO}_{2}(\mathrm{NK} / \mathrm{S}-\mathrm{Ratio})$.

Khorezm and the Karakum showed very similar results for the first three ratios $(\mathrm{K} / \mathrm{S}: 0.0301$ and $0.0305 ; \mathrm{S} / \mathrm{A}$ : 6.74 and 6.6; K/A: 0.2031 and 0.2012), indicating a strong chemical connection, either due to a similar geology or because of a stronger influence of dust from the Karakum and the nearby exposed floodplain of the Amu-Darya on Khorezm. The dust samples from these two regions also showed a characteristic as samples from Central Xinjiang, Inner Mongolia, and the Western Sahara [29, 30]. The Aralkum dust samples, on the other hand, were closer to the Kyzylkum samples and these two regions shared similarities with dust collected in Midwestern and Central China as well as with Southern Xinjiang [29, 31].

These results show that the four regions included in this study, even though they are close to each other, are exposed to the same climate, and have a similar geological background, show distinct differences in the collected dust samples. These reflect general physical characteristics (e.g. the much smaller average grain diameter in the Karakum) as well as anthropogenic influences (e.g. concentrations of phosphor in Khorezm and the Aralkum). These differences result in a unique finger print for each of these regions, which can be used to trace the dust from the three major dust sources in the Turan lowland - the Karakum, the Kyzylkum and the Aralkum. Continuing this research in the form of a longterm ground-based dust monitoring would allow a more accurate assessment of the often proclaimed health risk related to dust from the Aralkum.

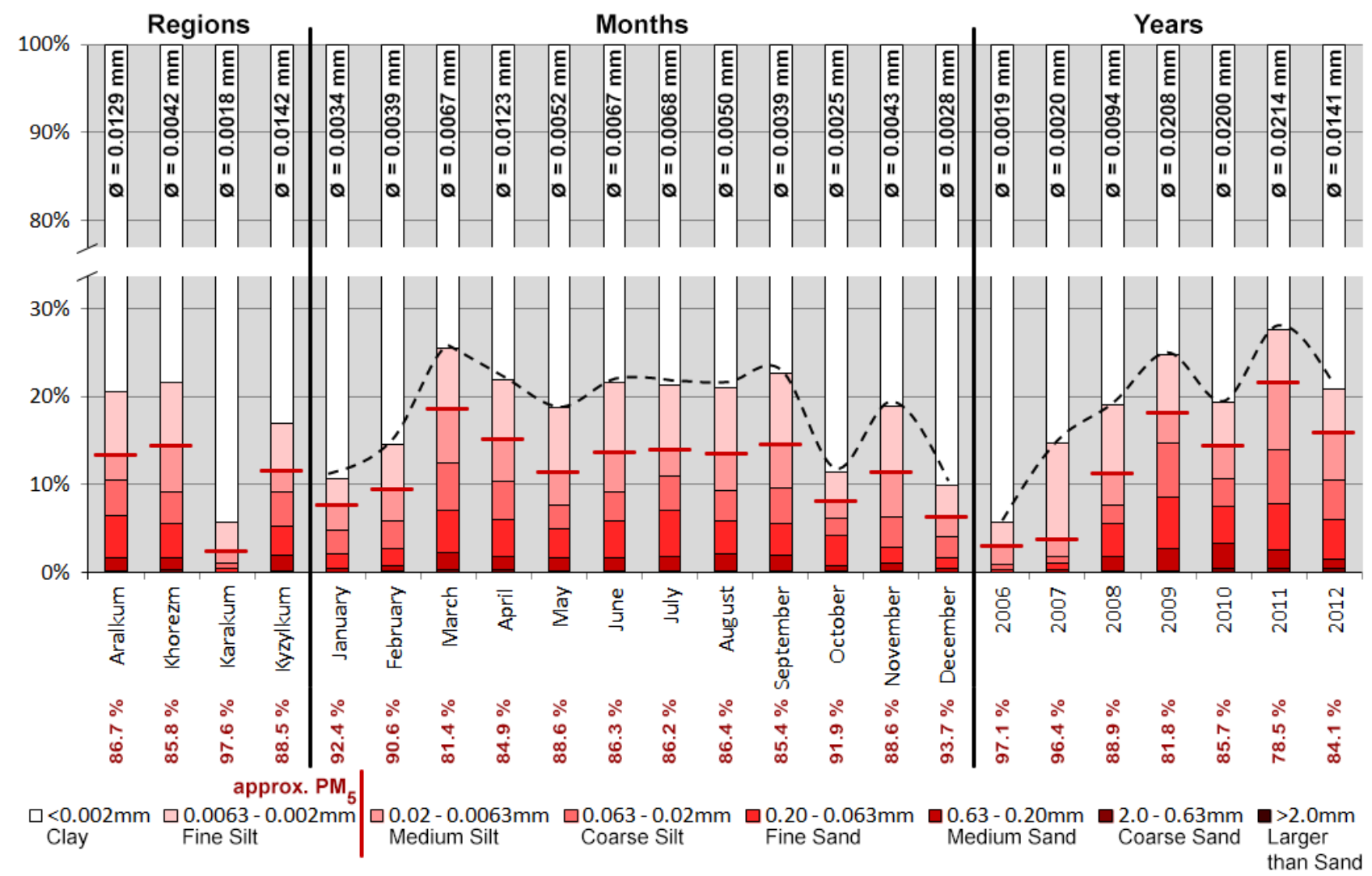




\section{References}

1. V. Chub, N. Agaltseva, S. Myagkrov, Proceedings of the International Conference on Hydrology and Watershed Management with the Focal Theme on Water Quality and Conservation, 2, 252-257 (2002)

2. C. Opp, M. Groll, Materials of the International Conference on Remote- and Ground-based Earth Observations in Central Asia, Bishkek, 265-271, DOI: $10.13140 / 2.1 .4224 .3840$ (2014)

3. C. Opp, Vom Aralsee zur Aralkum: Ursachen, Wirkungen und folgen des Aralsee-Syndroms. Asien, WBG, Darmstadt, 90-100 (2007)

4. S.P. Suslov, Moscow, 594 (1961) (in Russian)

5. V.A. Dukhovny, J.L.G. de Schutter, CRC Press, Leiden, 408 (2011)

6. M. Groll, C. Opp, I. Aslanov, Aeolian Research, 9, 49-62 (2013)

7. C. Opp, Geographische Rundschau International Edition, 1,2, 12-20 (2005)

8. C. Opp, M. Groll, Proceedings of the Marburg International Dust and Sandstorm Symposium, 29.09.-03.10.2009, 103 (2009)

9. T. Saiko, I.S. Zonn, Applied Geography, 20, 349-367 (2000)

10. M. Groll, R. Kulmatov, N. Mullabaev, C. Opp, D. Kulmatova, Environmental Earth Sciences, 75, 921, DOI: 10.1007/s12665-016-5691-5 (2016)

11. FAO, Land and Water Development Division, Rome, $28(2003)$

12. R.A. Kulmatov, M. Hojamberdiev, Journal of Environmental Science and Engineering, 4(8), 36-45 (2010)

13. R. Létolle, N. Aladin, I. Filipov, N.G.O. Boroffka, Mitig Adapt Strateg Global Change, 10, 51-70 (2005)

14. P.P. Micklin, Science, 241, 1170-1176 (1988)

15. S.L. O'Hara, G.F. Wiggs, B. Mamedov, G. Davidson, R.B. Hubbard, Lance, 355(9204), 627-628 (2000)

16. P. Whish-Wilson, J Rural Rem Environ Health, 1, 29-34 (2002)

17. G.F.S. Wiggs, S. O’Hara, J. Wegerdt, J. van der Meer, I. Small, R. Hubbard, Geogr J, 169, 142-157 (2003)
18. R. Zetterström, Acta Paediatr Suppl, 429, 49-54 (1999)

19. C. Opp, M. Groll, I. Aslanov, T. Lotz, N. Vereshagina, Quaternary International, 429, 86-99 (2017)

20. L. Orlovsky, G. Tolkacheva, N. Orlovsky, B. Mamedov, In: C.A. Brebbia (ed), Air Pollution, XII, 353-362 (2004)

21. R. Indoitu, L. Orlovsky, N. Orlovsky, Journal of Arid Environments, 85, 62-70 (2012)

22. G. Issanova, J. Abuduwaili, A. Kaldybayev, O. Semenov, T. Dedova, J Geological Society India, 3, 348-358 (2015)

23. L. Spivak, A. Terekhov, I. Vitkovskaya, M. Batyrbayeva, Curr. Prob. Remote Sens. Earth Space, 2,6, 193-202 (2009)

24. S. Brstilo, Q. Madunic (Eds.) Dust Storms. Elemental Composition, Causes and Environmental Impacts. Natural Disaster Research, Prediction and Mitigation Series. New York (2010)

25. C. Aranyi, J.L. Graf, W.J. O'Shea, J.A. Graham, F.J. Miller, Toxicology letters, 19, 63-72 (1983)

26. P. Dumortier, P. de Vuyst, J.C. Yernault, Environmental Health Perspectives, 102(5), 257-259 (1994)

27. S. Dai, L. Tian, C.L. Chou, Y. Zhou, M. Zhang, L. Zhao, J. Wang, Z. Yang, H. Cao, D. Ren, International Journal of Coal Geology, 76, 318-327 (2008)

28. P. Bennion, R. Hubbard, S. O'Hara, G. Wiggs, J. Wegerdt, S. Lewis, I. Small, J. van der Meer, R. Upshur, International Journal of Epidemiology, 36, 1103-1110 (2007)

29. Q. Feng, K.N. Endo, G.D. Cheng, Bull Eng Geol Env, 61, 253-261 (2001)

30. T. Moreno, X. Querol, S. Castillo, A. Alastuey, E. Cuevas, L. Herrmann, M. Mounkaila, J. Elvira, W. Gibbons, Chemosphere, 65, 261-270 (2006)

31. W. Ta, Z. Xiao, J. Qu, G. Yang, T. Wang, Environmental Geology, 43, 667-679 (2003) 